\title{
Upaya pemberian penyuluhan kesehatan tentang diabetes mellitus dan senam kaki diabetik terhadap pengetahuan dan keterampilan masyarakat desa Kedungringin, Wonogiri
}

\author{
Nita Yunianti Ratnasari \\ Akademi Keperawatan Giri Satria Husada Wonogiri, Indonesia \\ Corresponding Author \\ nitayr.gshwng@gmail.com
}

\begin{abstract}
Abstrak
Diabetes Mellitus (DM) merupakan penyakit kronik yang membutuhkan pengelolaan seumur hidup. Adapun maksud dan tujuan kami melakukan kegiatan penyuluhan kesehatan ini adalah untuk meningkatkan pengetahuan masyarakat tentang penyakit DM serta meningkatkan kesadaran masyarakat akan pentingnya melakukan senam kaki diabetik secara rutin untuk menurunkan kadar gula darah. Dalam kegiatan kali ini kami berperan sebagai penyuluh atau narasumber selama prosedur pelaksanaan senam kaki diabetik didemonstrasikan. Untuk memperlancar jalannya acara, kami juga dibantu oleh 10 mahasiswa semester VI. Rangkaian kegiatan dimulai dengan perkenalan, penjelasan maksud dan tujuan, penyampaian materi DM. Setelah semua materi tersampaikan dilanjutkan penataan lokasi untuk demonstrasi senam kaki diabetik. Peserta duduk diatas kursi yang telah disediakan. Semua terlihat cukup antusias mengikuti setiap instruksi dan contoh gerakan dari penyuluh. Setelah semua materi tersampaikan dilanjutkan evaluasi. Adapun evaluasi subyektif yaitu dengan menanyakan perasaan peserta setelah kegiatan; sedangkan evaluasi obyektif adalah dengan menanyakan kembali urutan gerakan senam kaki yang baru saja dipelajari. Hasil dari kegiatan penyuluhan kesehatan ini adalah terjadi peningkatan pengetahuan masyarakat tentang penyakit DM dan peningkatan kesadaran masyarakat akan pentingnya senam kaki diabetik.
\end{abstract}

Kata kunci: Penyuluhan kesehatan, diabetes mellitus, pengetahuan, keterampilan, senam kaki diabetik.

\begin{abstract}
Diabetes Mellitus (DM) is a chronic disease that requires continuous management. Related to the purpose and purpose of conducting this health education activity is to increase public knowledge about DM disease and increase public awareness about doing diabetic foot exercises regularly to increase blood sugar levels. In this activity, we invited as an instructor or resource person during the procedure to demonstrate diabetic foot exercises. To facilitate the running of the event, we were also invited by $10 \mathrm{VI}$ semester students. The series of activities begins with an introduction, an explanation of the intent and purpose, the delivery of DM material. After all the material has been delivered, set diabetic foot exercises. Participants who sit on the seats provided. All seemed enthusiastic enough to follow each instruction and example of the movement of the instructor. After all, the material is delivered. As a subjective evaluation, namely by asking participants
\end{abstract}


feelings after the activity; While objective evaluation is to re-ask for the sequence of foot exercises that have just been studied. The results of this health education activity were an increase in public knowledge about DM disease and an increase in public awareness of the importance of diabetic foot exercises.

Keywords: Health extension, diabetes mellitus, knowledge, skills, diabetic foot gymnastics.

\section{PENDAHULUAN}

Diabetes Mellitus (DM) merupakan sekelompok penyakit metabolik yang ditandai dengan hiperglikemi kronis akibat defek pada sekresi insulin, aksi insulin, atau keduanya (Habtewold, 2016). Penyakit ini secara signifikan meningkatkan resiko gangguan pada sistem kardiovaskuler, penyakit ginjal stadium akhir, kebutaan, amputasi sampai kematian (Fonseca et al., 2012), dimana terjadi peningkatan jumlah penderita dari tahun ke tahun (Lathifah, 2017). DM merupakan penyakit yang membutuhkan pengelolaan seumur hidup terkait monitoring kadar gula darah. Salah satu pengelolaan DM adalah melakukan aktivitas fisik termasuk di dalamnya senam kaki. Kebiasaan melakukan aktivitas fisik diharapkan akan mempengaruhi kadar gula darah penderita (Nur \& Wilya, 2014). Hasil Riset Kesehatan Dasar (Riskesdas) tahun 2018 menunjukkan bahwa secara nasional, prevalensi DM berdasarkan diagnosis dokter pada rentang usia 55-64 tahun menempati posisi tertinggi sebesar 6,3\%, disusul usia 65-74 tahun sebesar $6,0 \%$. Prevalensi nasional DM berdasarkan hasil pengukuran kadar gula darah pada penduduk umur $\geq 15$ tahun yang bertempat tinggal di perkotaan adalah 10,6\% (Kementerian Kesehatan, 2018).

Ulkus kaki merupakan salah satu komplikasi DM yang paling ditakuti, mengingat lama perawatan yang dibutuhkan serta biaya yang tidak sedikit untuk mencapai kesembuhan. Kejadian amputasi dapat dicegah jika penderita DM memiliki pengetahuan pentingnya aktivitas fisik guna mengontrol kadar gula (Dari et al., 2014). Namun, pada kenyataannya masih banyak masyarakat yang belum memahami sepenuhnya manfaat aktivitas fisik, khususnya senam kaki diabetik terhadap kadar gula darah. Hal ini menunjukkan pentingnya pemberian penyuluhan kesehatan kepada masyarakat khususnya para penderita DM untuk meningkatkan pengetahuan tentang penatalaksanaan penyakit DM serta keterampilan untuk menstabilkan kadar gula darah dengan demonstrasi teknik senam kaki. Sehingga pada akhirnya diharapkan kadar gula tetap stabil sekaligus dapat mencegah komplikasi lebih luas.

Berdasarkan latar belakang tersebut maka kami merasa tertarik untuk memberikan penyuluhan kesehatan tentang penyakit DM dan demonstrasi cara melakukan senam kaki diabetik. 


\section{METODE}

Rancangan kegiatan pengabdian masyarakat ini adalah berupa penyuluhan kesehatan tentang penyakit DM serta demonstrasi senam kaki diabetik. Khalayak sasaran adalah warga masyarakat desa Kedungringin Wonogiri, khususnya para penderita DM. Alat yang digunakan dalam kegiatan penyuluhan adalah laptop dan LCD, leaflet DM, sound system. Sementara alat yang digunakan pada saat demonstrasi senam kaki adalah kursi dan kertas koran.

Kegiatan ini dilaksanakan dalam satu periode waktu yaitu pada hari Jum'at, 22 Maret 2019. Rangkaian pelaksanaan kegiatan pada saat penyuluhan dilaksanakan, posisi penyuluh berada di depan audien, disamping layar LCD. Setelah penyuluhan materi DM selesai disampaikan, kegiatan dilanjutkan dengan demonstrasi senam kaki. Setting tempat diubah dengan menempatkan kursi secara melingkar dan penyuluh memposisikan diri di tempat yang dapat terlihat jelas oleh peserta. Kepada seluruh peserta dibagikan satu lembar kertas koran sebagai alat saat senam. Penyuluh melakukan gerakan senam kaki diikuti seluruh peserta yang hadir.

Pengumpulan data dilakukan dengan metode observasi kepada seluruh peserta. Kegiatan dibagi menjadi 3 fase, yaitu fase orientasi, kerja dan terminasi. Fase orientasi meliputi tahap perkenalan, penyampaian tujuan, validasi dan menanyakan kesiapan peserta. Fase kerja meliputi pengaturan posisi peserta, pengarahan awal kemudian dilanjutkan demonstrasi gerakan senam kaki dari awal sampai akhir dari penyuluh yang ditirukan seluruh peserta. Fase ketiga adalah terminasi yang berisi evaluasi jalannya kegiatan. Evaluasi ada 2, yaitu evaluasi subyektif dengan menanyakan perasaan peserta setelah semua sesi selesai dilaksanakan, serta evaluasi obyektif dengan menanyakan kembali materi senam kaki yang telah disampaikan.

Di bawah ini adalah ilustrasi seluruh rangkaian kegiatan penyuluhan yang disajikan dalam bentuk diagram flow. 
Indonesian Journal of Community Services

E-ISSN: 2684-8619

Volume 1, No. 1, Mei 2019

http://jurnal.unissula.ac.id/index.php/ijocs DOI: http://dx.doi.org/10.30659/ijocs.1.1.105-115

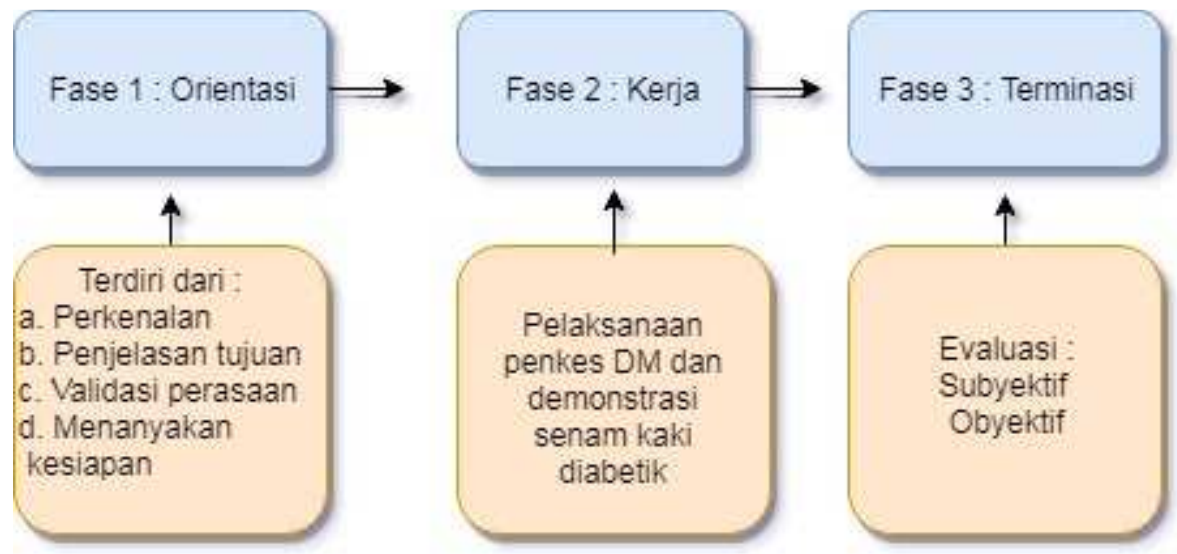

Gambar 1. Ilustrasi singkat rangkaian kegiatan penyuluhan kesehatan.

'Dari ilustrasi pada gambar 1 di atas terlihat bahwa rangkaian kegiatan dilakukan secara berurutan, dimulai dari fase orientasi. Fase ini bertujuan membina hubungan saling percaya antara penyuluh dengan peserta. Berikutnya fase kerja merupakan fase inti kegiatan yang berisi pemberian materi dan senam kaki diabetik. Fase terakhir adalah terminasi, merupakan fase evaluasi sekaligus penutupan acara.

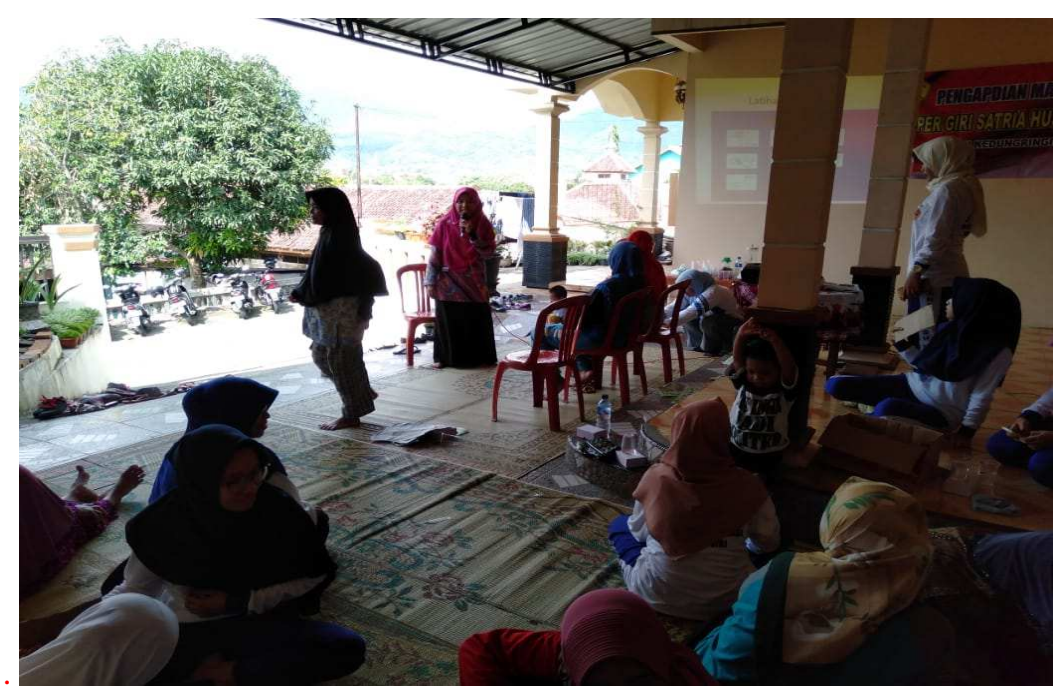

Gambar 2. Penyuluhan kesehatan DM.

Gambar 2 di atas adalah kondisi ketika penyuluh sedang menyampaikan materi tentang penyakit DM, meliputi definisi, tanda gejala, manifestasi klinis, komplikasi sampai dengan penatalaksanaan penyakit DM. Kegiatan ini berlangsung sekitar 15-20 menit. 


\section{Indonesian Journal of Community Services}

E-ISSN: 2684-8619

Volume 1, No. 1, Mei 2019

http://jurnal.unissula.ac.id/index.php/ijocs DOI: http://dx.doi.org/10.30659/ijocs.1.1.105-115

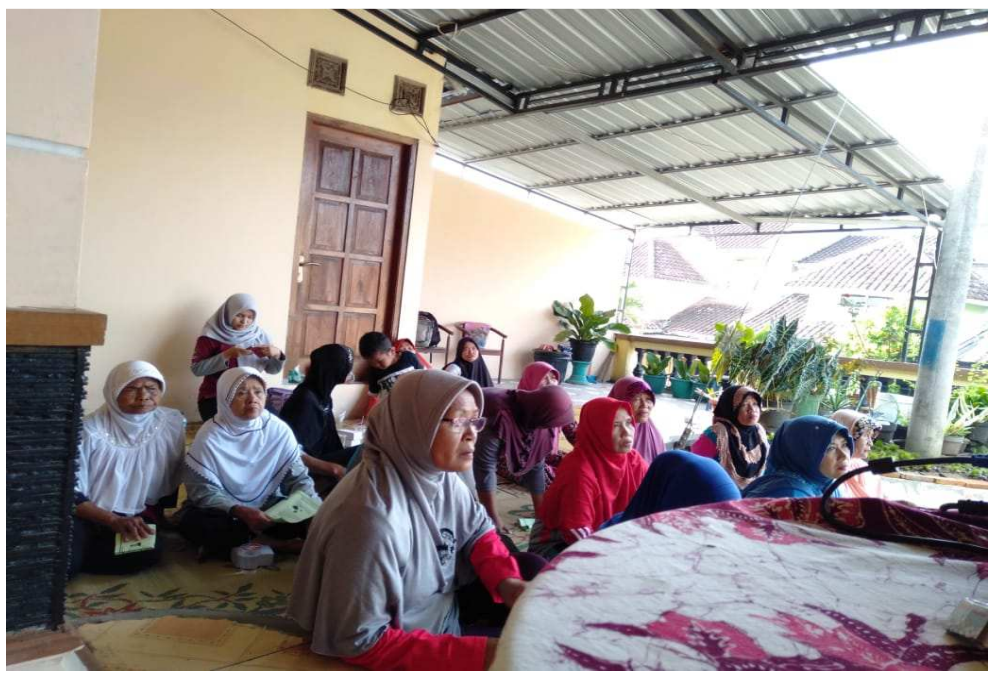

Gambar 3. Antusiasme peserta.

Pada gambar 3 tampak respon yang ditunjukkan peserta ketika materi disampaikan.

Terlihat semua sangat antusias memperhatikan setiap penjelasan dari penyuluh.

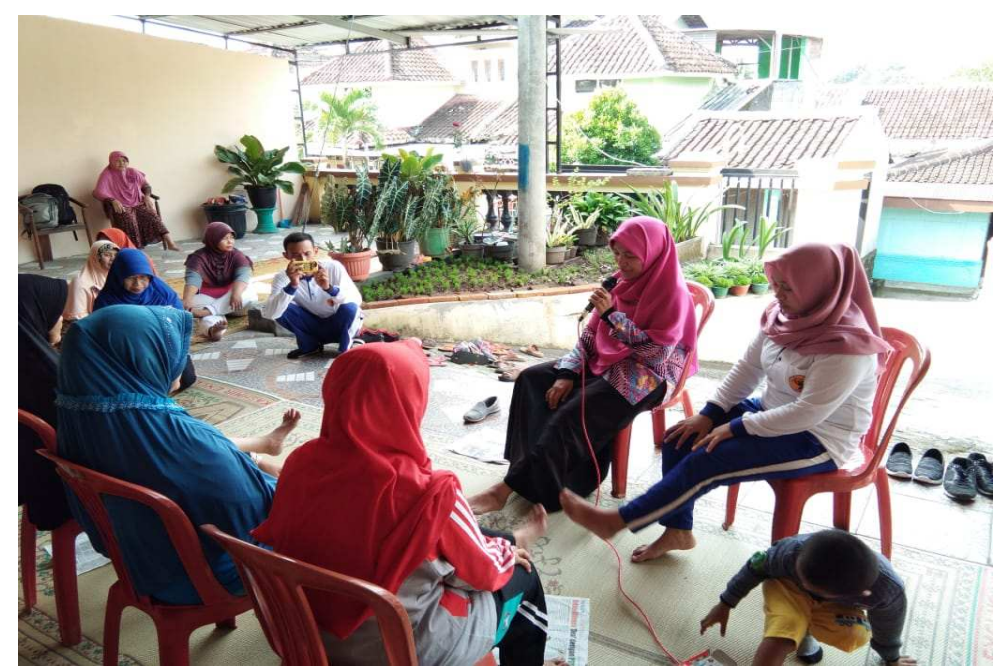

Gambar 4. Pelatihan senam kaki diabetik.

Gambar 4 menampilkan saat dimana penyuluh mendemonstrasikan gerakan senam kaki diabetik diikuti peserta dengan posisi duduk di atas kursi. Peserta terlihat sangat antusias menirukan setiap gerakan. Demonstrasi berlangsung sekitar 15 menit.

\section{HASIL DAN PEMBAHASAN}

Kondisi Geografis dan Kependudukan 
Kabupaten Wonogiri merupakan salah satu kabupaten di wilayah provinsi Jawa Tengah, yang dibentuk oleh Raden Mas Said (Pangeran Samber Nyawa). Pembentukan wilayah bermula dari daerah Nglaroh, pada tanggal 19 Mei 1741.

Letak Kabupaten Wonogiri secara geografis terletak pada garis lintang $7^{\mathrm{O}} 32^{\prime}-8^{\mathrm{O}} 15^{\prime}$ lintang selatan dan garis bujur $110^{\circ} 41^{\prime}-111^{\circ} 18^{\prime}$ bujur timur. Keadaan alamnya sebagian besar terdiri dari pegunungan yang berbatu gamping, terutama di bagian selatan, termasuk jajaran pegunungan seribu, yang merupakan mata air dari Bengawan Solo, walaupun ada juga daerah dataran maupun daerah pantai. Posisi kabupaten Wonogiri sangat strategis karena terletak di ujung selatan provinsi Jawa Tengah dan diapit oleh provinsi Jawa Timur dan provinsi Daerah Istimewa Yogyakarta. Berdasarkan Kantor Catatan Sipil kabupaten Wonogiri Tahun 2015, menunjukkan bahwa kabupaten Wonogiri memiliki luas wilayah sebesar 182.236,0236 ha $(1.822,36 \mathrm{~km} 2)$. Kabupaten Wonogiri memiliki 25 kecamatan, 43 kelurahan dan 251 desa. Kecamatan terjauh dari pusat kota adalah kecamatan Paranggupito, sejauh 68 km, sedangkan kecamatan terdekat adalah kecamatan Selogiri. Kecamatan Puhpelem yang memiliki luas wilayah 3.162 ha yang sekaligus merupakan kecamatan tersempit wilayahnya, sedangkan kecamatan yang paling luas adalah kecamatan Pracimantoro seluas $142,1 \mathrm{~km}^{2}$. Adapun kecamatan Karangtengah adalah kecamatan yang paling tinggi lokasinya yang berada pada ketinggian 600 meter di atas permukaan air laut dan yang paling rendah adalah kecamatan Selogiri (Wonogiri, 2017).

Berdasarkan data profil kesehatan kabupaten Wonogiri menunjukkan bahwa penduduk kabupaten Wonogiri pada tahun 2015 paling banyak dalam katagori "tidak/belum tamat SD" dan "SD/MI" yakni sebesar 30,025\%. Dibandingkan pada tahun 2014 yaitu sebesar 18,91\% dalam kategori tidak/belum tamat SD dan 36,59\% dalam kategori SD/MI,sehingga dalam 2015 mengalami peningkatan pada jumlah kategori tidak/belum tamat SD sebanyak 11,11\%, dan mengalami penurunan dalam kategori SD/MI sebesar 6,56. Pada tahun 2015 ada 4 kategori yang mengalami penurunan, yaitu kategori SD/MI turun dari 36,59\% menjadi 30,025\%, SLTP/MTs turun dari $18,88 \%$ menjadi $14,59 \%$, SLTA/MA turun dari $12,12 \%$ menjadi $11,28 \%$ dan universitas mengalami penurunan dari 2,06\% menjadi 1,40\%. Apabila dibandingkan dengan tahun 2014, menunjukkan bahwa terdapat banyak penurunan, yang disebabkan akibat tingkat perekonomian masyarakat yang menurun sehingga semakin banyak yang putus sekolah. Untuk memperbaiki keadaan pendidikan di kabupaten Wonogiri, sebaiknya pemerintah setempat memberi beasiswa untuk melanjutkan sekolaha atau sekolah dasar Gratis (Wonogiri, 2017).

\section{Pengetahuan}


DM merupakan penyakit metabolik yang ditandai dengan timbulnya hiperglikemia akibat gangguan sekresi insulin, dan atau peningkatan resistensi insulin seluler terhadap insulin. Hiperglikemia kronik dan gangguan metabolik DM lainnya akan menyebabkan kerusakan jaringan dan organ, seperti mata, ginjal, syaraf, dan sistem vaskular. Ulkus diabetikum merupakan salah satu komplikasi diabetes melitus pada sistem integumen, diawali dengan adanya rasa baal atau kesemutan. Kebiasaan maupun perilaku masyarakat seperti kurang menjaga kebersihan kaki dan tidak menggunakan alas kaki saat beraktivitas akan beresiko terjadi perlukaan pada daerah kaki. Keadaan kaki diabetik lanjut yang tidak ditangani secara tepat dapat/berkembang menjadi suatu tindakan pemotongan amputasi kaki. Adanya luka dan masalah lain pada kaki merupakan penyebab utama kesakitan morbiditas, ketidakmampuan disabilitas, dan kematian mortalitas pada seseorang yang menderita DM (Priyanto et al., 2013) . Pengetahuan tentang penyakit DM mutlak diperlukan mengingat penyakit ini tergolong kasus serius dimana terjadi peningkatan jumlah penderita dari tahun ke tahun. Estimasi terakhir IDF, terdapat 382 juta orang yang hidup dengan diabetes di dunia pada tahun 2013. Pada tahun 2035 jumlah tersebut diperkirakan akan meningkat menjadi 592 juta orang. Diperkirakan dari 382 juta orang tersebut, 175 juta di antaranya belum terdiagnosis sehingga terancam berkembang progresif menjadi komplikasi tanpa disadari dan tanpa pencegahan. DM merupakan penyakit gangguan metabolik menahun akibat pankreas tidak memproduksi cukup insulin atau tubuh tidak dapat menggunakan insulin yang diproduksi secara efektif. Insulin adalah hormon yang mengatur keseimbangan kadar gula darah. Akibatnya terjadi peningkatan konsentrasi glukosa di dalam darah (hiperglikemia) (Kementerian Kesehatan, 2014).

Ditinjau dari karakteristik responden diperoleh data bahwa rerata responden berusia antara 50 sampai 60 tahun. Hal ini sesuai dengan hasil penelitian yang dilakukan terhadap pasien DM di RSUD Dr. Moewardi Surakarta yang menyatakan bahwa rerata pasien DM berusia > 40 tahun, dan berjenis kelamin perempuan (Witasari et al., 2013). Walaupun DM merupakan penyakit kronik yang tidak dapat menyebabkan kematian secara langsung, tetapi dapat berakibat fatal bila pengelolaannya tidak tepat. Pengelolaan DM memerlukan penanganan secara multidisiplin yang mencakup terapi non-obat dan terapi obat. Penyakit DM memerlukan perawatan medis dan penyuluhan untuk self management yang berkesinambungan untuk mencegah komplikasi lebih lanjut (Putri \& Isfandiari, 2013).

Kegiatan penyuluhan kesehatan dapat dilakukan melalui penyuluhan kelompok dan penyuluhan masa, sedangkan kegiatannya dilakukan oleh Puskesmas, Rumah Sakit dan Dinas Kesehatan maupun lembaga-lembaga lainnya. Edukasi merupakan pendidikan atau latihan mengenai pengetahuan dan keterampilan dalam pengelolaan DM yang diberikan kepada setiap 
pasien (Putri \& Isfandiari, 2013). Pengetahuan yang baik merupakan kunci keberhasilan dari manajemen DM (Windasari et al., 2009). Semakin tinggi pengetahuan yang dimiliki oleh pasien maka dapat meningkatkan kepatuhan. Pengetahuan tersebut meliputi pengetahuan yang didapat secara aktif misalnya melalui membaca buku dan mendapatkan pendidikan kesehatan dari petugas kesehatan (Hokkam, 2009).

Demikian halnya dengan kegiatan penyuluhan kesehatan yang dilakukan di desa Kedungringin, Wonogiri. Masyarakat cukup antusias mengikuti seluruh rangkaian kegiatan dari awal sampai akhir. Peserta yang hadir bukan saja mereka yang menderita DM, namun banyak juga kalangan warga masyarakat yang sehat. Hal ini menunjukkan tingginya kebutuhan masyarakat akan pemberian informasi kesehatan serta tingkat kesadaran masyarakat akan pentingnya hidup sehat yang semakin membaik.

\section{Senam Kaki Diabetik}

Penatalaksanaan senam kaki diabetik sangat besar manfaatnya bagi penderita DM. Sebuah studi yang pernah dilakukan di kabupaten Sangihe menunjukkan bahwa senam kaki yang dilakukan oleh penderita DM berpengaruh pada penurunan kadar gula darah. Aktivitas yang dilakukan penderita dapat menekan terjadinya kenaikan gula darah. Dari penelitian yang dilakukan, para penderita dapat menyadari pentingnya senam kaki ataupun melakukan aktivitas. Upaya dalam mengendalikan gula darah tidak efektif hanya dilakukan dengan pengobatan saja. Hal tersebut dikarenakan penderita yang mengalami DM disebabkan oleh kerusakan pankreas dalam meproduksi insulin, dimana insulin ini berfungsi dalam mengendalikan kadar gula darah. Untuk menunjang peran pankreas yang mengalami kerusakan tadi, perlu didukung faktor lain yang mempunyai fungsi yang sama yaitu dalam mempengaruhi produksi gula darah. Faktor penting lain tersebut adalah diet dan latihan. Diet berkaitan dengan pemilihan dan kepatuhan dalam mengkonsumsi makanan yang mengandung kadar gula yang dianjurkan. Terutama makanan yang rendah gula. Adapun latihan yang dianjurkan adalah aktivitas yang dapat membantu menurunkan kadar gula darah seperti jalan-jalan, senam tubuh dan senam kaki sesuai kebutuhan dan kemampuan (Ruben et al., 2016).

Studi senam kaki yang dilakukan di Manado menunjukkan kemudahan dari gerakan senam kaki, dimana senam kaki diabetes ini dapat dilakukan dengan mudah karena hanya menggunakan koran dan kursi, dapat dilakukan kapan saja dan dimana saja tanpa mengganggu aktivitas yang lainnya, tidak memerlukan biaya yang banyak, tidak menyebabkan kelelahan atau membuang energi yang banyak, dan memiliki manfaat yang banyak bagi penyandang DM (Mangiwa et al., 2017). 
Gerakan senam kaki juga terdapat peregangan kaki (stretching). Stretching kaki dianggap efektif melancarkan sirkulasi darah ke daerah kaki, meningkatkan kerja insulin dan melebarkan pembuluh darah dimana insulin bekerja menghambat proses lipolysis, yaitu penguraian trigliserida menjadi asam lemak dan gliserol, sehingga terjadi penurunan pengeluaran asam lemak yang berlebihan dari jaringan adipose ke dalam darah, mengurangi resiko arterosklerosis, serta dapat meningkatakan aliran darah ke estremitas bawah dan berperan serta meningkatkan tekanan sistolik pada kaki (Yasa et al., 2013). Studi serupa tentang senam kaki juga pernah dilakukan Manado yang menyatakan adanya pengaruh senam kaki diabetes terhadap nilai Ankle Brachial Index, hal tersebut dapat dilihat melalui uji Wilcoxon Sign Rank test pada hasil observasi nilai Ankle Brachial Index sebelum diberikan intervensi senam kaki diabetes dan hasil observasi nilai Ankle Brachial Index setelah diberikan intervensi berupa senam kaki diabetes pada 30 responden dengan tingkat kepercayaan 95\% dan tingkat kemaknaan $\alpha=0,05$ (Mangiwa et al., 2017).

\section{KESIMPULAN}

Rekomendasi yang diberikan pada kegiatan pengabdian masyarakat ini adalah disarankan untuk senantiasa melakukan senam kaki ini setiap hari selama 30 menit selain untuk mencegah luka diabetes juga dapat mengontrol gula darah. Rekomendasi untuk perawat yang ada di Puskesmas untuk membuat Standar Operasional Prosedur (SOP) sebagai bentuk meningkatkan kualitas asuhan keperawatan pada pasien DM. Untuk penelitian selanjutnya diharapkan membandingkan efektifitas senam kaki diabetik terhadap gula darah, sensitifitas kaki, capillary refill time serta menambahkan banyak sampel.

\section{UCAPAN TERIMA KASIH}

Ucapan terima kasih disampaikan kepada Direktur Akademi Keperawatan Giri Satria Husada Wonogiri, Kepala UPTD Puskesmas Wonogiri II beserta jajarannya, serta seluruh warga masyarakat desa Kedungringin, Wonogiri atas bantuan dan partisipasinya dalam kegiatan pengabdian masyarakat ini.

\section{DAFTAR PUSTAKA}

Dari, NW, Nurchayati, S., Hasanah, O. (2014). Pengaruh pendidikan kesehatan senam kaki melalui media audio visual terhadap pengetahuan pelaksanaan senam kaki pada pasien 
dm tipe 2. JOM PSIK, 1(2):1-7.

Fonseca, VA., Kirkman, MS., Darsow, T., Ratner, RE. (2012). The American Diabetes Association Diabetes Research Perspective. Diabetes Care. 2012;35. doi:10.2337/dc129001.

Habtewold, TD, Tsega, WD, Wale, BY. (2016). Diabetes Mellitus in Outpatients in Debre Berhan Referral Hospital, Ethiopia. J Diabetes Res. doi:s http://dx.doi.org/10.1155/2016/3571368.

Hokkam, EN. (2009). Assessment of risk factors in diabetic foot ulceration and their impact on the outcome of the disease - Primary Care Diabetes. Prim Care Diabetes, 3(4):219-224. doi:https://doi.org/10.1016/j.pcd.2009.08.009

Kementerian Kesehatan. (2018). HASIL UTAMA RISKESDAS 2018. In: Riskesdas 2018. Jakarta: Balitbangkes, 071118; 2018:1-200. http://www.depkes.go.id/resources/download/info-terkini/hasil-riskesdas-2018.pdf.

Kementerian Kesehatan. Situasi dan Analisis Diabetes. (2014). In: INFODATIN. Pusat Data Dan Informasi Kementerian Kesehatan RI. Jakarta: Kementerian Kesehatan RI; 2014:17. http://www.depkes.go.id/resources/download/pusdatin/infodatin/infodatindiabetes.pdf.

Lathifah, NL. (2017). Hubungan durasi penyakit dan kadar gula darah dengan keluhan subyektif penderita diabetes melitus. J Berk Epidemiol, 5(2):231-239. doi:10.20473/jbe.v5i2.2017.231-239.

Mangiwa, I., Katuk, ME. \& Sumarauw, L. (2017). Pengaruh senam kaki diabetes terhadap nilai ankle brachial index pada pasien diabetes melitus tipe ii di rumah sakit pacaran kasih gmim manado. ejournal keperawatan (e-Kp), 5(1). https://media.neliti.com/media/publications/105018-ID-pengaruh-senam-kaki-diabetesterhadap-ni.pdf.

Nur, A., Wilya, V, Ramadhan, R. (2014). Kebiasaan aktivitas fisik pasien diabetes mellitus terhadap kadar gula darah di Rumah Sakit Umum dr. Fauziah Bireuen. SEL.;3(2):41-48.

Priyanto, S., Sahar, J., \& Widyatuti. (2013). Pengaruh senam kaki terhadap sensitivitas kaki dan kadar gula darah pada aggregat lansia diabetes melitus di Magelang. Pros Konf Nas PPNI JAWA Teng 2013. 2013:76-82.

Putri, NHK. \& Isfandiari, MA. (2013). Average Blood Sugar and Diabetus Mellitus Type II Management Analysis. J Berk Epidemiol, 1(2):234-243. http://www.journal.unair.ac.id/filerPDF/jbed89640f867full.pdf.

Ruben, G., Rottie, J., \& Karundeng, MY. (2016). Pengaruh senam kaki diabetes terhadap perubahan kadar gula darah pada pasien diabetes melitus tipe 2 di wilayah kerja puskesmas Enemawira. eJournal Keperawatan (eKp), 4(1):1-5. https://media.neliti.com/media/publications/105933-ID-pengaruh-senam-kaki-diabetesterhadap-pe.pdf.

Windasari, NN., Wibowo, S., \& Afandi, M. (2009). Kedokteran F, Gajah U, Yogyakarta UM. Pendidikan Kesehatan dalam Meningkatkan Kepatuhan Merawat Kaki pada Pasien Diabetes Mellitus Tipe II. Muhammadiyah J Nurs (Tovar 2007):61-67. 
http://journal.umy.ac.id/index.php/ijnp/article/view/670.

Witasari, U., Rahmawaty, S., Zulaekah, S. (2009). The relationship between level of knowledge, intake of carbohydrate and fiber and blood glucose level in home cared type 2 diabetic patients. J Penelit Sains Teknol, 10(2):130-138.

https://publikasiilmiah.ums.ac.id/xmlui/bitstream/handle/11617/440/4. UCIK c.pdf?sequence $=1 \&$ is Allowed $=y$.

Wonogiri B. Profil Kesehatan Kabupaten Wonogiri Tahun 2017. In: Wonogiri: BPS Wonogiri; 2017:1-72. https://wonogirikab.bps.go.id/publication/download.html?nrbvfeve=MTQzZDc5ZTZm MjI1ZTZmN2M1N2JiNGVj\&xzmn=aHR0cHM6Ly93b25vZ2lyaWthYi5icHMuZ28ua WQvcHVibGljYXRpb24vMjAxOC8xMi8yNi8xNDNkNzllNmYyMjVINmY3YzU3Y mI0ZWMvcHJvZmlsLWtlc2VoYXRhbi1rYWJ1cGF0ZW4td29ub2dpcmktMjAxNy5od G1s\&twoadfnoarfeauf=MjAxOS0wMy0yNCAxNDo0NDozOQ\%3D\%3D.

Yasa, ID., Endang, VM., Bagiarta, I., \& Zumla A. (2013). Latihan aerobik jalan kaki pada pasien diabetes. Jur Keperawatan Politek Kesehat Denpasar. http://poltekkesdenpasar.ac.id/files/JURNAL GEMA KEPERAWATAN/JUNI 2014/Dewa Putu Gede Putra Yasa, dkk.pdf. 